\title{
Approach Higher Order Thinking-Problem Based Learning in Learning Mathematics Material Linear Equations Absolute Value One Variable
}

\author{
Anik Kirana ${ }^{1}$ \\ Siti Kholifah ${ }^{2}$ \\ ${ }^{1}$ Universitas Wijaya Kusuma Surabaya \\ ${ }^{2}$ SMK Negeri 8 Surabaya \\ Email: kiranaanik10@gmail.com
}

\begin{abstract}
ABSTRAK
Dalam pembelajaran di sekolah masih banyak dijumpai guru menggunakan model pembelajaran yang berpusat pada guru atau Teacher Center. Dalam pembelajaran yang berpusat pada guru, guru dapat mengendalikan atau mengorganisasikan materi dan waktu sepenuhnya, tetapi komunikasi hanya terjadi satu arah sehingga pembelajaran berjalan pasif. Kondisi pembelajaran yang berpusat pada guru tidak sesuai dengan yang diharapkan dalam Permendiknas 2006 yaitu dalam belajar matematika diharapkan siswa memiliki kemampuan berpikir logis, analitis, sistematis, kritis, dan kreatif, serta mempunyai kemampuan bekerja sama. Salah satu model pembelajaran yang dapat membantu siswa mengembangkan kemampuan berpikir kritis dan logis adalah Problem Based Learning (PBL). Dalam $P B L$,fungsi guru adalah sebagai fasilitator yang berarti menyiapkan segala fasilitas yang diperlukan dalam kegiatan pembelajaran. PBL menjadi lebih baik jika dikaitkan dengan pendekatan Higher Order Thinking (HOT) karena muara dari pola berpikir tingkat tinggi adalah mampu menyelesaikan masalah. Dari hasil pengamatan terhadap aktivitas belajar siswa dengan pendekatan HOT-PBL meliputi aktivitas yaitu: aktivitas motorik, aktivitas mental, dan aktivitas emosi siswa selama pembelajaran berlangsung di dalam kelas dengan pendekatan HOT-PBL mendapatkan kategori baik, yang artinya siswa tergolong siswa aktif. Sedangkan dari hasil tes yang meliputi soal HOT-PBL diperoleh ketercapaian ketuntasan sebasar 85,7\% yang artinya terdapat 85,7\% siswa yang mencapai ketuntasan individual.
\end{abstract}

Kata Kunci: Aktivitas, Hasil Belajar, Higher Order Thinking-Problem Based Learning

\begin{abstract}
In learning in schools there are still many teachers using a teacher-centered learning model or Teacher Center. In teacher-centered learning, the teacher can control or organize the material and time completely, but communication only occurs in one direction so that learning runs passively. Teacher-centered learning conditions are not as expected in the 2006 Ministry of Education Regulation, which is expected to learn mathematics in students having the ability to think logically, analytically, systematically, critically, and creatively, and have the ability to work together. One learning model that can help students develop critical and logical thinking skills is Problem Based Learning (PBL). In $P B L$, the teacher's function is as a facilitator which means preparing all the facilities needed in learning activities. PBL becomes better if it is associated with the approach Higher Order Thinking (HOT)because the estuary of higher-order thinking patterns is able to solve problems from the observations of student learning activities the HOT-PBL approach includes activities namely: motor activity, mental activity, and emotional activity students during learning take place in the classroom with the HOT-PBL approach get a good category, which means students are classified as active students. While the results of the test which includes HOT-PBL questions obtained $85.7 \%$ mastery achievement which means that $85.7 \%$ of students achieved individual completeness.
\end{abstract}

Keywords: Activities, Learning Outcomes, Higher Order Thinking-Problem-Based Learning 


\section{INTRODUCTION}

One important factor in developing and building a nation is education. Through education the nation's abilities can be developed and the character and dignity of a nation's civilization can be formed. Improving the quality of education is a top priority in educating the life of the nation so that the nation not only has the ability of knowledge and skills, but also can think critically and creatively in solving a problem.

At every level of education starting from kindergarten to high school / vocational mathematics become one of the subjects taught. Even in higher education in several study programs, mathematics is one of the courses that must be programmed.

The foregoing shows that mathematics has an important role in everyday life. Besides mathematics is also a basic science that is very useful as a means of logical thinking, scientific, and has the influence to support the success of students in taking education.

In learning in schools there are still many teachers who use a teacher-centered learning model or Teacher Center. In teacher-centered learning, the teacher can control or organize the material and full time, but communication only occurs in one direction so that learning runs passively,

Based on Permendiknas (2006: 361) it is stated that in learning mathematics students are expected to have the ability to think logically, analytically, systematically , critical, and creative, and have the ability to work together.

The ability to think logically, analytically, systematically, critically, and creatively, and have the ability to work together can be achieved if in learning activities, a teacher applies a learning model that can help students develop thought patterns. With these abilities students will be able to solve various contextual problems.

One learning model that can help students develop critical and logical thinking skills is Problem Based Learning. Nurhadi (2004: 109) states that Problem Based Learning is a learning model that uses real world problems as a context for learning about critical thinking and problem solving skills, and obtaining essential knowledge and concepts from subjects.

Problem Based Learning (PBL) is a student-centered learning model. PBL is a learning model that can be used to activate students (Abbas, 2007: 8).

In PBL, the teacher's function is as a facilitator which means preparing all the facilities needed in learning activities. With these facilities students are expected to become more active. The expected activeness during learning is to actively ask questions, express opinions, answer questions, and be active in discussions.

PBL becomes better when it is associated with the approach Higher Order Thinking (HOT)because the estuary of a higher level of thinking is able to solve problems (Widodo, 2013: 164).

HOT can invite students to actively think in problem solving. As indicators are (1) showing the ability to understand the problem that is organizing relevant data, presenting the problem clearly, (2) choosing a model or strategy for solving, (3) being able to apply the chosen model or solving strategy, and (4) being able to check back against problem solving.

One of the mathematical material in class $\mathrm{X}$ majoring in Fashion Management at SMK Negeri 8 Surabaya is Equation and Inequality of Absolute Linear One Variable Value. In this material is very laden both concepts and skills that must be possessed by students.

By paying attention to the characteristics of this material, student activeness is very much needed in order to obtain maximum learning outcomes. Therefore we need a certain learning model so that it can help students in solving contextual problems that are assembled with the material equation and linear inequality of the absolute value of one variable.

This Higher Order Thinking-Problem Based Learning (HOT-PBL) approach is an approach that is still rarely used by teachers in 
schools. At SMK Negeri 8 Surabaya, especially in learning mathematics has not implemented PBL which is associated with HOT. This paper was made to describe the activities and learning outcomes of class $\mathrm{X}$ students majoring in Clothing, especially in class X-TBs 2 of SMK Negeri 8 Surabaya in learning that is carried out by applying HOT-PBL to the subject matter of equations and linear inequality of absolute values of one variable.

\section{LITERATURE REVIEW}

Problem Based Learning (PBL) in Indonesian is called Problem Based Learning (PBM). The PBL model was developed based on the concepts put forward by J. Bruner namely learning discovery or discovery learning. The concept of discovery learning is one of the theories that support the development of PBL models, namely as a model that is oriented at the ability to manage information.

Suyatno (2009) states that PBL is a problem-based learning model, where the problem is used as a stimulus that encourages students to use their knowledge to formulate a hypothesis, the search for relevant information that is student-centered through discussion in a small group to get solutions from problem given.

While Barbara J. Duch (1996) in Wijayanto (2009:15) argues that PBL is a model that is characterized by the use of problems in the real world to train students to think critically and skillfully solve problems, and gain knowledge about important concepts from what learned.

Arend in Trianto (2007) explained that PBL is a learning approach where students are faced with authentic (real) problems so that they are expected to be able to compile their own knowledge, develop high-level skills and inquiry, independent students, and increase their confidence.

According to Sanjaya (2006: 214), PBL is a series of learning activities that emphasizes the process of solving problems faced scientifically. The nature of the problem raised in Problem Based Learning is the gap or gap between the real situation and the expected situation, or between what happens with expectations.

According to Abbas (2007: 8), the learning model Problem Based Instruction (PBI) centers on student activities. The learning model is one of the learning models that teachers can use in activating students in learning. Problem Based Instruction in terms of linking new information with cognitive structures owned by students through learning activities in social interactions with other friends (Rusman, 2012: 245).

Based on the opinions above it can be concluded that PBL is a learning model oriented to problems that occur in the real world. The problem arises because of the gap between the real situation and the expected situation. Learning activities that emphasize solving these problems can be used to develop high-level skills, independent attitude, logical thinking, and increase self-confidence.

The characteristics of the learning model are the characteristics possessed by a learning model. The PBL model has characteristics that are typical of the PBL model.

Trianto (2009: 93) states the characteristics of the Problem Based Learning (PBL) learning model are: (1) the existence of asking questions or problems, (2) focusing on interdisciplinary linkages, (3) authentic inquiry, (4) producing 
products or works and present it, and (5) cooperation.

Furthermore Rusman (2010: 232) states that the characteristics of the PBL model are (1) Problems become the starting point in learning, (2) Problems raised are problems that exist in the unstructured real world, (3) Problems require multiple perspectives (multiple perspective ), (4) Problems challenging students' knowledge, attitudes, and competencies which then require identification of learning needs and new fields of learning, (5) Learning selfdirection becomes the main thing, (6) Utilization of diverse knowledge sources, their use, and evaluation of information sources is an essential process in problem based learning, (7) Learning is collaborative, communication, and cooperative, (8) The development of inquiry and problem solving skills is as important as mastering the contents of knowledge to find solutions to problems, (9 ) Synthesis and integration of a learning process, (10) Problem based learning involves evaluations and review student experiences and learning processes.

Some learning objectives using the PBL model are:

1. Develop thinking skills and problem solving skills.

2. Learn the role of adults.

3. Skills for independent learning.

The syntax of PBL models in learning is as follows:

1. Learner orientation to the problem;

2. Organizing students to learn;

3. Guiding individual and group investigations;

4. Develop and present the work; and

5. Analyzing and evaluating the problem solving process.
Each learning model has strengths and weaknesses. The following are the strengths of the PBL model, namely:

1. Learning centered on students;

2. Develop students' self-control;

3. Allows learners to learn events in a multidimensional and in-depth manner;

4. Developing problem solving skills;

5. Encouraging students to learn new material and concepts when solving problems;

6. Develop social skills and communication skills that enable them to learn and work in teams;

7. Developing high-level scientific thinking skills.

The weaknesses of using PBL learning model are as follows (Sanjaya, 2006: 221):

1. When students have no interest or students assume that the problem being studied is difficult to solve, they will feel reluctant to try.

2. The success of the learning model through Problem Based Learning requires enough time to prepare.

3. Without understanding why students are trying to solve the problem being studied, students will not learn what they want to learn.

\section{METHODE}

\section{HOT-PBL Approach}

Higher-Order Thinking (HOT) is a skill students must have because problems in real life are complex, have many variables, and require more than memorizing facts or concepts.

HOT-PBL is a learning approach that also uses real-world problems as a context for students to learn about ways of thinking and problem solving abilities, as well as to obtain essential knowledge and concepts from subject matter. This learning can encourage students to find reasons for true solutions (learn to reason 
correct solutions) and further encourage students to build, construct and maintain correct argumentative solutions (learn to construct and defend reasonable solutions). The syntax of Problem Based Instruction PBI) and indicators of HOT-PBI questions by Krathwohl (in Lewy, 2009).

Table 1. Syntax Problem Based Instruction (PBI)

\begin{tabular}{|l|l|}
\hline No & Problem Based Instruction \\
\hline 1. & Orienting students to the problem \\
\hline 2. & Organizing students to learn \\
\hline 3. & $\begin{array}{l}\text { Guiding authentic individual or } \\
\text { group inquiry }\end{array}$ \\
\hline 4. & $\begin{array}{l}\text { Developing and presenting the } \\
\text { work }\end{array}$ \\
\hline 5. & $\begin{array}{l}\text { Analyzing and evaluating the } \\
\text { problem solving process }\end{array}$ \\
\hline
\end{tabular}

Table 2 Indicators High Level Thinking or HOT

\begin{tabular}{|c|c|c|c|}
\hline $\begin{array}{l}\mathbf{N} \\
\mathbf{0}\end{array}$ & $\begin{array}{l}\text { Problem } \\
\text { indicators }\end{array}$ & $\begin{array}{l}\text { Categor } \\
\mathbf{y}\end{array}$ & Indicators \\
\hline 1. & $\begin{array}{l}\text { Plan the } \\
\text { purpose } \\
\text { behind the } \\
\text { information } \\
\text { has been } \\
\text { obtained on } \\
\text { the social } \\
\text { arithmetic }\end{array}$ & $\begin{array}{l}\text { Analyze } \\
\text { (analyze) }\end{array}$ & $\begin{array}{l}\text { Clarificatio } \\
\mathrm{n} \text { of issue } \\
\begin{array}{l}\text { Disclosure } \\
\text { opinions }\end{array}\end{array}$ \\
\hline 2. & $\begin{array}{l}\text { Finding } \\
\text { discrepancie } \\
\mathrm{s} \text { or errors } \\
\text { between } \\
\text { process and } \\
\text { outcome, } \\
\text { determining } \\
\text { that the } \\
\text { process and } \\
\text { results of } \\
\text { compatibility } \\
\text {, or test the } \\
\text { consistency } \\
\text { of a problem }\end{array}$ & $\begin{array}{l}\text { Evaluate } \\
\text { (evaluate } \\
\text { ) }\end{array}$ & $\begin{array}{l}\text { Evaluation } \\
\text { and } \\
\text { implementa } \\
\text { tion } \\
\text { Evaluation }\end{array}$ \\
\hline
\end{tabular}

\begin{tabular}{|l|l|l|}
\hline & $\begin{array}{l}\text { by using } \\
\text { various } \\
\text { solutions to } \\
\text { social } \\
\text { arithmetic. }\end{array}$ & \\
\hline 3. & $\begin{array}{l}\text { Describe a } \\
\text { problem so }\end{array}$ & \\
that it can & (create) & \\
make & & \\
allegations \\
that lead to \\
problem \\
solving by \\
trying to \\
prepare a \\
settlement \\
plan based \\
on methods \\
that already \\
exist in \\
social \\
arithmetic \\
material.
\end{tabular}

\section{Student Activity}

Effective learning is learning that gives students the chance to study or do their own activities. Students can learn while working. Diedrich (in Asih, 2013) said that many activities that students can do during learning are:

1. Visual activities (viewing), which include: paying attention to pictures, conducting experiments, responding to other people's work.

2. Oral activities (speaking), which include among others: stating, formulating, asking, giving advice, issuing opinions, conducting interviews, discussions, interruptions.

3. Listening activities (listening), which include among others: listening to the description, conversation, discussion, music, speeches.

4. Writing activities, which include: writing stories, essays, reports, questionnaires, copying. 
5. Drawing activities (drawing) included include: drawing, making maps, charts, graphs.

6. Motor activities (motor activities), which include, among others: conducting experiments, making construction, repair models.

7. Mental activities (mental activities), which include, among others: responding, remembering, solving problems, analyzing, making relationships, making decisions.

8. Emotional activities (emotional activities) included are: interested, feeling bored, excited, excited, passionate, brave, calm, nervous.

In this writing the student activities described are: Motor activities which include reading LKPD, writing (which are relevant to learning activities), Mental activities (mental activities) which include listening / paying attention to teacher explanations, discussing / asking questions between students, discussing / ask questions between students and teachers, Emotional activities (emotional activities) which include the enthusiasm of students in solving problems.

\section{RESULTS AND DISCUSSION}

\section{Learning Results}

Learning outcomes are abilities possessed by students after participating in learning activities. Learning outcomes have a very important role in the learning process. Learning outcomes can be used to measure the extent to which abilities are achieved by students after the end of a learning activity. According to Sudjana (2013: 22) learning outcomes are abilities possessed by students after receiving their learning experience. Namawi (in Susanto, 2013: 5) states that learning outcomes can be interpreted as the level of success of students in learning subject matter in school which is stated in the scores obtained from test results regarding a number of subject matter specific.

The description of student learning outcomes in this paper is obtained from the test results of learning the material of equations and linear inequality of the absolute value of one variable. The test is given at the end of learning one basic competency. Furthermore, to measure student achievement, the minimum completeness criteria (KKM) used by the State Vocational School 8 Surabaya is used, namely individual students are said to have completed if they reach a minimum value of 75 , and classical completeness is set with a minimum criteria of $85 \%$ of students completing.

\section{Description of Student Activities}

The object observed was the activity of class XTBs2 students of SMK Negeri 8 Surabaya while participating in mathematics learning using HOT-PBL. Analysis of student activity observation data was calculated by determining the percentage of each category of student behavior that appeared. To find the percentage of student activities observed in learning used the formula:

P : Description:

P: Activity percentage figures

: Frequency of each aspect of observation

: number of frequencies for each aspect of observation

Table 3 Percentage Score of Student

\begin{tabular}{|l|l|}
\hline $\begin{array}{l}\text { ActivityActivity } \\
\text { Presentation } \\
\text { Student }\end{array}$ & Category \\
\hline $0 \% \leq \mathrm{P}<20 \%$ & Less Once \\
$20 \% \leq \mathrm{P}<40 \%$ & Poor \\
$40 \% \leq \mathrm{P}<60 \%$ & Fair \\
$60 \% \leq \mathrm{P}<80 \%$ & Good \\
$80 \% \leq \mathrm{P}<100 \%$ & Good One \\
\hline
\end{tabular}

(Adapted, Suharsimi Arikunto 2009)

Suitability of student activity is based on the time allocation set in the RPP with the limitation criteria as in the table above.

The observed student activities are: (1) Motor activities, which include: orientation of the problem, namely students reading the problem, analyzing, and digging information, both of which students can determine the main 
problem including determining the mathematical model, and the third is organizing students to learn, which consists of conducting individual or group investigations, which are divided into one part, namely students formulating hypotheses, (2) mental activities, which include: answering questions, asking questions, solving problems, and make conclusions. (3) Emotional activities (emotional activities) included include: paying interest, feeling bored, excited, excited, passionate, brave, calm, nervous.

Based on observations on student activities, it can be described as follows: indicators reading problems, analyzing, and digging up information, can be categorized as good, because many students ask questions about things they do not understand from LKPD. At each meeting the time spent reading the LKPD exceeds the ideal time because this is due to many students from the lower class who spend a lot of time reading. By reading students can analyze and explore information which is very important in the orientation phase of the problem. Discuss / ask fellow friends both in one group and ask the teacher can be categorized enough. This shows that the teacher must motivate students to discuss / ask questions among friends in the group. This is very important to do in the phase of organizing students in study groups. In learning, students look very enthusiastic when presenting the results of their work. This shows that the emotional activity of students is very good.

\section{Description of Student Learning Outcomes}

Learning outcomes tests are given at the end of learning to determine the achievement of competencies that have been learned.

From the results of these tests, it appears that after learning mathematics the material of equations and linear inequality the absolute value of one variable using HOT-PBL there are 30 students out of 35 students achieving completeness or as much as $85.7 \%$ of students who complete. The test questions given are HOT-PBL tests totaling 4 items done in 90 minutes. The way of assessment is seen from several stages namely students must be able to determine what is known and asked on the problem, students can determine the mathematical planning model and students can determine to carry out calculations The highest score obtained by 2 students who each got a score of 90 and the lowest value of 46 . The number of students who take the test is 35 students. students can be said to be complete if they meet the limitations of learning outcomes $\geq 75$.

Based on the classical mastery learning criteria set by the 2013 curriculum, student learning completeness is achieved. From the results of daily tests showed that there were 30 students out of 35 students who had finished. This shows that the learning outcomes of students after participating in learning with the HOT-PBL model have reached completeness both individually and classically.

\section{CONCLUSION}

Based on the above description, it can be concluded that: Student learning activities with the HOT-PBL approach include activities namely: motor activities, mental activities, and emotional activities of students while learning takes place in class with the HOT-PBL approach getting good categories, which means students are classified as active students. Student learning outcomes with the HOT-PBL approach reached $85.7 \%$ of completeness which means that there were $85.7 \%$ of students who achieved individual completeness.

\section{REFERENCES}

Abbas. (2007). Model-model Pembelajaran Berbasis Masalah. Jakarta: Balai Pustaka

Arends, Richard I. (2008). Learning to Teach. Yogyakarta: Pustaka Pelajar.

Arikunto, S. (2009). Prosedur Penelitian Suatu

Pendekatan Praktek. Jakarta : Rineka Cipta.E.A. 
Asih, Nadia Nurmala. (2013). Keefektifan Model Pembelajaran Knisley dengan Metode Brainstorming Berbantuan CD Pembelajaran Terhadap Kemampuan Pemahaman Konsep Siswa Kelas X. Skripsi tidak diterbitkan. Semarang: FMIPA UNNES

Lewy. (2009). Pengembangan Soal untuk Mengukur Kemampuan Berpikir Tingkat Tinggi Pokok Bahasan Barisan dan Deret Bilangan di Kelas IX Akselerasi SMP Xaverius Maria Palembang. (Jurnal Pendidikan Matematika, Volume 3.No.2, Desember 2009)

Nurhadi. (2004). Pembelajaran Kontekstual dan Penerapannya dalam KBK. Malang: UM Malang

Rusman. (2012). Belajar dan pembelajaran berbasis komputer mengembangkan profesional guru abad21. Bandung: Alfabeta

Sudjana, Nana. (2013). Penilaian Hasil Proses Belajar Mengajar. Bandung: Remaja Rosda Persada

Suyatno. (2009). Menjelajah Pembelajaran Inofatif. Sidoarjo: Masmedia Buana Pusaka.

Sanjaya, W. (2006). Strategi Pembelajaran. Jakarta: Kencana Prenada Media Group.

Trianto. 2007. Model - model Pembelajaran Inovatif Berorientasi Konstruktivistik. Jakarta: Prestasi Pustaka.

Permendiknas. (2006). Standar Kompetensi Lulusan untuk Satuan Pendidikan Dasar dan Menengah, No. 23 Tahun 2006. Diakses dari https://akhmadsudrajat.files.wordpress.co m/2012/01/nomor-23-tahun 2006. pdf, pada tanggal 18 Oktober 2016.

Widodo, Tri dan Sri Kadarwati. (2013). Higher Order Thinking Berbasis Pemecahan Masalah Untuk Meningkatkan Hasil Belajar Berorientasi Pembentukan Karakter Siswa. Semarang. Diunduh tanggal 4 November 2018 pukul 16.46, hlm 170 